Western University

Scholarship@Western

Aboriginal Policy Research Consortium International (APRCi)

1999

\title{
Letters from Mapoon: Colonising aboriginal gender
}

Regina Ganter

Griffith University

Follow this and additional works at: https://ir.lib.uwo.ca/aprci

Part of the Other Sociology Commons

Citation of this paper:

Ganter, Regina, "Letters from Mapoon: Colonising aboriginal gender" (1999). Aboriginal Policy Research Consortium International (APRCi). 371.

https://ir.lib.uwo.ca/aprci/371 
This article was downloaded by: [University of Western Ontario]

On: 16 December 2012, At: 07:22

Publisher: Routledge

Informa Ltd Registered in England and Wales Registered Number: 1072954 Registered office: Mortimer House, 37-41 Mortimer Street, London W1T 3J H, UK

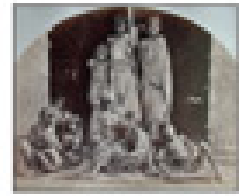

Antratise misterive Mediet

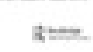

\section{Australian Historical Studies}

Publication details, including instructions for authors and subscription information: http:// www. tandfonline.com/loi/ rahs20

\section{Letters from Mapoon: Colonising aboriginal gender} Regina Ganter ${ }^{\text {a }}$

${ }^{a}$ Griffith University,

Version of record first published: 30 Sep 2008.

To cite this article: Regina Ganter (1999): Letters from Mapoon: Colonising aboriginal gender , Australian Historical Studies, 29:113, 267-285

To link to this article: http:// dx. doi.org/ 10.1080/10314619908596102

\section{PLEASE SCROLL DOWN FOR ARTICLE}

Full terms and conditions of use: http://www.tandfonline.com/page/terms-and-conditions

This article may be used for research, teaching, and private study purposes. Any substantial or systematic reproduction, redistribution, reselling, loan, sub-licensing, systematic supply, or distribution in any form to anyone is expressly forbidden.

The publisher does not give any warranty express or implied or make any representation that the contents will be complete or accurate or up to date. The accuracy of any instructions, formulae, and drug doses should be independently verified with primary sources. The publisher shall not be liable for any loss, actions, claims, proceedings, demand, or costs or damages whatsoever or howsoever caused arising directly or indirectly in connection with or arising out of the use of this material. 


\section{Letters from Mapoon: Colonising Aboriginal Gender*}

\section{REGINA GANTER}

Much information on traditional indigenous society in Australian historiography and anthropology stems from the vast store of eyewitness accounts left by missionaries, settlers and government officials. How cautious does one need to be in using such material? After all that it reveals about the moral and legal universe of its writers, can it speak reliably about traditional society? This article traces the production of knowledge about indigenous gender relations at Cape York Peninsula through a lineage of sources from the 1890s to the 1990s and concludes that unless the assumptions embedded in the primary sources are clearly identified, the discourse on Aboriginal womanhood continues to be a colonising project.

SOME YEARS AGO, I was asked to comb through the correspondence (mostly handwritten in German) of the missionaries of Mapoon. Weipa and Aurukun to see what they might yield on traditions of the Wik Munkan people. The Moravian missionaries arrived in Mapoon in 1892, when the period of intensive contact had only just commenced in western Cape York Peninsula, and stayed for twentyfive years. Wading through the voluminous material, which contains ample reference to traditional ways, I was struck by the paucity of description and the overwhelming dominance of moralising interpretation.

More unsettling still was the gradual realisation that what appeared to be the mutual corroboration of several eyewitness accounts revealed itself as the mirroring of accounts which then became cemented as the master narrative of race relations in the pearling and beche-de-mer industry of North Queensland. These northern marine industries had a particularly bad reputation where contact with Aborigines was concerned. Prostitution was said to characterise the contact between the pearl-shell and beche-de-mer luggers and coastal Aborigines and bribery was alleged to be the normal mode of recruiting because the bêche-de-mer industry attracted 'the lowest class of whites' and employed many Asians.'

The production and circulation of such knowledge, which remains the

\footnotetext{
* Thanks to Eddie Woodley (Marpuna), Patrick Sullivan (North Australia Research Unit), Hilary Carey (Newcastle) and Paul Turnbull (James Cook University) for fruitful discussions and relevant material, to Christa Loos for endless evenings spent deciphering German handwriting, to Peter Sutton for arranging financial assistance with translations, and to David Lea, Henry Chan, Franson Mansali and Paul Bourke for organising venues to discuss various versions of this paper.

1 William Parry-Okeden, 'Report on the North Queensland Aborigines and the Native Police', Queensland Votes and Proceedings (hereafter QVP), vol. 2, 1897. For a discussion of the extent to which the substantial involvement of Asians in these industries coloured official positions on race relations, see Regina Ganter, 'Living an Immoral Life: "Coloured" Women and the Patemalistic State', Hecate, vol. 24, no. 1, 1998, pp. 13-40.
} 
dominant narrative of these industries, raises formidable problems for understanding the history of the Cape York area. The indistinctness between corroboration and reiteration casts a heavy shadow on a historiographical tradition that privileges written sources over oral ones. Tracing a lineage (not a comprehensive genealogy) of knowledge of race/gender relations-and by implication of womanhood-at Cape York Peninsula reveals an interweaving of colonising discourse that is difficult to untangle.

In particular, this essay examines how the interaction of Aboriginal women with non-Aboriginal men in the pearl-shelling and bêche-de-mer industry came to be indiscriminately labelled as prostitution, a term that must be ethnographically suspect and one that relies for its salience on a particular view of gender relations. ${ }^{2}$ An account of traditional gender relations will not be attempted through the filter of these sources but it is instructive to look at the filter itself: at the historical texts that reflect images of gender and at the conditions of production of such texts. What emerges from such an analysis is the intricate relationship between power and knowledge to which discourse analysis has sensitised us but that can also be traced without resort to neologisms or a cumbersome theoretical framework.

Two problematic characteristics shape the genesis of this lasting portrayal of race relations in north Australia. First, it germinated from particular presumptions built into the primary texts, presumptions that have been carried over a number of texts even into quite recent anthropological and historical accounts. Second, the production, acceptance and reproduction of primary accounts has its own social dynamics. At the turn of the century, the professional concern with Aborigines in north Queensland rested with a circumscribed set of people who formed a close-knit web of information and friendship. The missionary at Mapoon will serve to illustrate the mechanism of knowledge construction in this fabric of communication.

Power: 'shaking off the sinful'

Nicholas Hey was from rural Bavaria and arrived, aged twenty-nine, in early 1892, fresh from the missionary training college to establish a new Moravian mission on the west coast of Cape York Peninsula. ${ }^{3}$ He was introduced to northern society by John Douglas, a former premier of Queensland and then the government

2 See, for example: Anne de Soyza, 'The Analysis of Prostitution', in Penelope Hetherington and Philippa Maddern (eds), Sexuality and Gender in History: Selected Essays, University of Western Australia Press, Perth, 1993, pp. 95-110; and Ann McGrath, Borm in the Cattle: Aborigines in Cattle Country, Allen \& Unwin, Sydney, 1987, p. 69.

3 The Moravian missions in Victoria were being abandoned due to dwindling numbers and Hey, once established at Mapoon, initiated the setting up of further missions at Weipa (Embley River, Albatross Bay, 1896) and Aurukun (Archer River, 1904). The Queensland government was well disposed towards these missions and at first funded them so liberally that Hey was unable to spend the allocated sum each year. Nicholas Hey to Governor La Trobe, 18 December 1896, Annual Report from Mapoon, Mf 186, Australian Institute of Aboriginal and Torres Strait Islander Studies (hereafter AIATSIS). 
resident on Thursday Island. Douglas had been instrumental in facilitating the establishment of the new mission, and visited Mapoon regularly. He established a close friendship with Hey, at whose wedding he acted in loco parentis.

Four weeks after Hey's arrival at Mapoon, he was joined by the Reverend James Ward and his wife, who was Hey's sister. Ward (who had been intended as the intellectual leader of the mission) died shortly afterwards and Hey remained in charge of the mission, assisted by his wife and sister. It is impossible to judge from his reports how much of the work was shouldered by his assistants, let alone by native workers, but the impression gained from his accounts is that he was an ardent worker. Within two months of his arrival in the bush, he had erected a house, a chicken coop (on the second day), a bush house, planted three hundred fruit trees, adopted a boy, nursed some sick people, befriended some children with gifts and started to evangelise with daily readings, using some local vocabulary and a lot of flour to attract an audience. ${ }^{4}$ Hey was above all a practical man, with training in carpentry, blacksmithing and gardening, as well as Latin, French, Greek, Hebrew and some English.

The mission site had been selected because it was an area of intensive recruitment for pearl-shelling luggers, a traditional meeting place for a number of subgroups. Some four hundred Aborigines were in contact with the mission but there were never more than one hundred present at any one time, except at the annual Christmas festivities when presents were given by the missionaries. Throughout the twenty-five year period of the missionaries' presence, the mission battled with fluctuating attendance as subgroups arrived and departed on their seasonal cycles of movement. Encouraging a sedentary lifestyle became central to the missionaries' efforts. The missionaries started to attract locals by offering food and trade goods in exchange for work. They also attended to wounds and diseases and opened a school. Attendance at the school did not exceed forty children until the government started to transfer children of mixed descent to the mission in 1905. These children were categorised as neglected childen and often remained from early childhood until they were married. It was only with this shift in government policy towards using existing missions as state schools that sedentarism became a significant feature of mission life..$^{5}$ On all North Queensland missions, the imposition of a sedentary and monogamous way of life

\footnotetext{
4 'Whenever I came to the camp all the women and children fled, but through little presents I soon had the children on my side. I also looked after the sick. One man had a leg wound which I nursed, another was unable to obtain food for himself, and soon he recovered under my care ... I found a little boy who had no parents, and since he had no name I called him Willie. I made him a pair of pants. He is useful to me, fetching my water and doing other little services.' Hey to [O']Connor, 7 March 1892, Mf 186, AlATSIS.

- Generally the state government used the placement of 'neglected' children to subsidise the missions. However, at Mapoon: The finances of the Institution are apparently in a prosperous condition, and Rev. Mr. Hey tells me that he is .willing to take more "neglected" children without payment'. Chief Protector Roth to Undersecretary for Public Lands, 1 October 1905. item 1295/5, A/44680, Queensland State Archives (hereafter QSA). The first such child was placed at Mapoon in 1901. Roth Progress Report, October 1901, A/114679, QSA. With the departure of Roth and Douglas from the north, the mission's relationship with the state government became increasingly difficult.
} 
was central in the struggle against 'satanism'. But the greatest effort-with the greatest promise of success-was spent on the young, for whom dormitories were established to separate them from the influence of their parents when they reached school age. ${ }^{6}$

The mentality of governing required that, in order to manage these institutionalised bodies, they had to be administratively created first. The children were allocated birthdays spread evenly over the calendar year ${ }^{7}$ and, as keeper of records, the missionary also had the power of naming:

I envisage to give two names to each baptismal candidate. Deindidtschi is Jimmy's real name, his father, brother and sisters have the same name ... I have entered both names for him because we have several Jimmies. As far as I can tell Deinditschy [sic] has no special meaning. It is a very old name and there is a little bird here by the same name. I could not make out whether the name stems from the bird. I am not especially fussed about beautiful names or their meaning, otherwise I might have chosen a nicer name but I do not wish to interfere too deeply with the existing conditions, only to shake off the sinful.s

Hey invoked criteria of morality and aesthetics to justify this regime of naming. But naming is of course an exercise of power. If an indigenous name was used, the problem of correct pronounciation and comprehension rested with the missionary. By substituting a Christian name, that disadvantage was reversed.

The first baptisms of an Aboriginal couple were in 1896 and gradually a small nucleus of a Christian community formed, which after ten years counted eighteen adult members. Hey deplored that he had no power to conduct marriages because there was no white population at Mapoon and the black population had its own marriage rules. ${ }^{9}$ But it was exactly the traditional marriage rules that Hey sought to contest. Without power to conduct (monogamous) marriages, Hey for a while considered taking people who were living in polygamous marriages into baptismal classes but then decided against it. Living according to Christian principles, and therefore disavowing polygamy, became a condition for entry into the privileged nucleus of named Christians.

Hey saw the polygynous marriage system as objectifying and oppressing women:

- Noel Loos, 'Concern and Contempt: Church and Missionary Attitudes towards Aborigines in North Queensland in the Nineteenth Century', in Tony Swain and Deborah Bird Rose (eds). Aboriginal Australians and Christian Missions: Ethnographic and Historical Studies, Australian Association for the Study of Religions, Bedford Park, 1988, pp. 100-20.

7 Hey to La Trobe, 2 April 1897, Mf 186, AIATSIS.

- Hey to La Trobe, n.d., page behind Hey to La Trobe 28 October 1899, Mf 186, AIATSIS.

- Hey to La Trobe, 2 April 1897, Mf 186, ALATSIS. At this time, Aboriginal policy in Queensland was in its formative stage and tribal marriages were still recognised. Ordained in Ireland, Hey was apparently not licenced to perform marriages in Queensland, normally a process put in train by the ordaining church office through the registrar-general. From enquiries at the Queensland State Archives and the Presbyterian Archives in Queensland, I could not ascertain whether Hey was subsequently vested with such powers. In 1908, Hey was vested with the power to consent to the marriage of minors, presumably because he was acting in loco parentis for minors resident at Mapoon. Registrar-General to HeY, 24 February 1908, A/58912, QSA. 
It is not the women who are dependent on the men but the men rely on the women, i.e. the women are the wealth of the men. The more women he has, the greater is the mighty man. Moreover the women bring home most of the food stuffs, and two women bring home more than one. ${ }^{10}$

The Christian influence, accordingly, was seen as liberating for women. In 1898 , Hey commented that an improvement in the treatment of women was highly noticeable. By this time, several young couples had been settled on outstations and allocated land for farming. They were required to live in monogamy for one year in order to be eligible for baptismal classes. They were also taught the gender roles appropriate to Christian living. The man of each couple was required to build a little house (one of them took a year to complete the unusual task); the men were to engage in agriculture and, for the women, sewing classes were offered. ${ }^{11}$ Hey's comments give a glimpse of how these couples played along with the missionary's gender game:

In the evenings I generally take a stroll into the village and have a chat with each individual, and enquire whether the plants have been watered, but that is not thought of. If the women happen to be present it is easy, the men order them straight away to water the plants, orders which are carried out but sparingly. But if the women are absent it is more difficult. They will have a pain in the back or will have sustained an injury of some sort which is not visible but all the more painful, but there will be hope of recovery on the next day, and there is nothing that can be done about it. ${ }^{12}$

If the missionary could not accept that gardening was women's work and would only accept illness as an excuse from the chore, then illness was the excuse supplied.

Enforcing monogamy among Christian couples was a constant battle. In 1898, Hey reflected:

Okee still has his two wives and it would not be difficult to part with one if he only wanted to ... I am of the opinion that where there is serious yearning for truth and light, the difficulties in this respect will disappear. ${ }^{13}$

In the following year, Hey described the pressures of tradition, which continued to present a powerful challenge to the new order.

A young widow from one of the neighbouring tribes was to fall to Jimmie according to the old customs and traditions and he was pressed from many quarters to accept this widow as his second wife. But as soon as he hesitated and showed an inclination to give in his wife S. came into the mission house and announced it. I at once went into the village and Jimmie explained he had to take the woman, it was the custom ... I only told Jimmy that if he gave in I could no longer be his friend. ${ }^{14}$

\footnotetext{
10 Hey to La Trobe, 28 March 1898, Mf 186, ALATSIS.

$"$ Hey to La Trobe, 8 August 1898, Mf 186, AIATSIS.

12 Ibid.

13 Hey to La Trobe, 28 March 1898, Mf 186, AIATSIS.

14 Hey to La Trobe, n.d., Annual Report for 1900, Mf 186, AlATSIS.
} 
Hey then gathered the parishioners to 'pray the devil out of Mapoon'. The levirate, so familiar in the Old Testament, ${ }^{15}$ became the subject of open exorcism.

This episode, incidentally, provides one of the rare glimpses into the effect of the mission on personal lives to be gleaned from Hey's correspondence. As an evangelist, Jimmy had been a showcase of the mission's success but, after this incident, only negative reference is made to him. Hey records that Jimmie eventually resigned himself to monogamy. He also discontinued his annual winter visits to his country on the Coen River and there was an outburst of domestic violence. It may be assumed that his standing in traditional society suffered considerably as a result of his failure to fulfil his traditional obligations and it is likely that the showdown with Hey undermined his position in the mission community. Having functioned as an arbiter between Christianity and tradition, he lost his authority-and utility-in both worlds.

Hey strongly contested traditional law. He devised rules on an ad hoc basis in order to construct himself as an alternative locus of authority and power. For example, about a month after his arrival Hey witnessed the ritual spearing of a woman. He immediately set himself up as the chief arbiter of conflict and 'took all his spears from the perpetrator'. ${ }^{16}$ In another instance, he offered a man who had consorted with a married woman the choice to be either punished by traditional law (most likely a ritual spearing) or by himself, in which case the punishment would be the loss of wages, consisting of a pair of trousers and a blanket, which would be given to the woman's husband in compensation. It is easy to see to which authority the offender would have chosen to submit. ${ }^{17}$

His good relationship with the government resident underwrote Hey's authority. He could for example plead for leniency for offenders before the magistrate if they submitted to his authority and gave themselves up. ${ }^{18} \mathrm{Absconders}$ from the pearl-shelling luggers frequently sheltered behind his authority, so that master pearlers alleged the existence of a regular refugee trail of absconders who would allow themselves to be recruited at Mapoon and abscond at Cape Grenville on the other side of Cape York to return overland. They referred to the 'Halleluja

1s See the well-known story of Rachel, who was betrothed at a tender age by her father, Laban, in order to secure the labour of Jacob, whose second wife she became.

16 Ritual spearing as a way of settling disputes usually involved throwing a spear at the leg of the person to be punished but, in this case, the woman was speared in the neck. Hey summarised the incident: 'Because the men have several wives this gives rise to much argument and fight and if I may say so it has become the fashion that the man gives away his wife if he doesn't fancy her or that the woman runs away with another man which always results in much argument. One sin gives rise to the next, and this is how it was this time. Bamptrin's sister left her husband Charlie because she preferred the so-called Captain Cook. Her brother would only accept it if Cook gave him his sister in compensation, who was however also married. Cook could not satisfy this requirement because his sister did not want to leave her rightful husband, and Bamptrin therefore decided to kill his sister'. Hey to [O']Connor, 20 January 1892, Mf 186 , AIATSIS.

17 Hey to La Trobe, 8 August 1898, Mf 186, AIATSIS.

ts Hey to Römig, 6 August 1896; and Hey to La Trobe, 2 April 1897, Mf 186, AlATSIS. 
band' at Mapoon who waited for a 'free cruise' to Thursday Island whence they would abscond with a supply of stores. ${ }^{19}$

The animosity between master pearlers and the missionary was mutual. Hey was an outspoken opponent of recruiting, which he saw as demoralising.

In the course of this report, I could not avoid touching slightly on some of the evils arising in connection with the recruiting of natives ... The natives are recruited often willingly enough. They have heard strange tales of the sea from their friends and they are willing to go on a cruise for a time. They do not think of the money they will receive for their labour, that is of no consequence to them, because they receive little benefit from it. Sooner or later the novelty wears off and they are anxious to return to their own country. They talk of this amongst themselves, seize the first favourable opportunity and make a dash for freedom ... From my observation and experience gained by living almost 6 years amongst the natives I believe only by absolutely prohibiting the employment of aborigines in the pearlshell, turtle $\&$ beche-de-mer industry, could the existing evils be remedied and future evils prevented.20

Knowledge production: 'speaking from my experience'

In the above account, Hey explicitly speaks as an eyewitness, from his six years of experience at Mapoon. This eyewitness status lends authority to his account. But the following account of recruiting for the fishery had been rendered by Douglas some years earlier (all emphases are mine):

They are recruited often willingly enough. They have heard strange tales of the sea from their friends, and they are willing to go on a cruise for a time. They are shipped with the vaguest possible idea of their duties or their obligations. They perhaps work willingly enough for a time, especially if they are well fed. But whether they are fed well or ill, whether they are badly treated or not, there comes over them, long before the expiry of their legal agreement, an irrepressible desire to return to their own country and to the tribal usages. They talk of this among themselves. There are always some of them who know enough about the navigation of a lugger to enable them to reach the mainland. Then they agree to seize the first favourable opportunity, and they make a dash for freedom. ${ }^{21}$

The point does not need labouring that the similarity in expression weakens the authority of Hey's 'eyewitness' account. At this time, the Queensland government had been alerted to the maltreatment of Aborigines, especially in the remote north, and two exhaustive reports were tabled in preparation for the 1897

19 Torres Strait Pilot, 13 October 1894. After recruiting at a camp or mission, the luggers needed to return to Thursday Island to have the new recruits signed on.

${ }^{20}$ Hey to Colonial Secretary, 1 July 1897, (in English), Mf 186, AlATSIS. Emphases in the following seven extracts are mine.

21 Douglas to Colonial Secretary, 16 February 1893, printed as appendix B in 'Report of the Government Resident at Thursday Island for 1892-93', QVP, vol. 2, 1894, pp. 14-15. 
legislation. Hey and Douglas were key informants for both reports. One of these reports reads:

The pearl-shell boats are mischievous nuisance to the Batavia River missionaries. Even on the morning of my arrival ... I saw a lugger just leaving the anchorage off the open beach about a mile behind the Mission Station. She had anchored there on the previous night, sent the boats ashore, bought half-a-dozen women, took them on board all night, and returned them next moming. Most of the blacks were away using the flour and tobacco which formed one of the terms of contract. These practices are well known to the boys and girls on the Mission; and if the schoolgirls were not under proper control and guarded at night, the old men of the tribe would periodically dispose of them in a similar manner. These undesirable marine visitors sometimes leave a legacy of disease, and always a certain demoralisation against which the missionaries have to wage perpetual warfare.

The chief trouble is with the old men who have a plurality of wives. One of these aboriginal Mormons possessed eight partners. ${ }^{22}$

This author (Archibald Meston) also pointed out his eyewitness status to authenticate his account. Hey wrote in the following year:

There is no doubt the blacks are a dying race, consumption, as well as other diseases carrying off many in their prime. But we are glad that in the eventide of the nations [sic] story there is light. A new and eternal day has dawned for many and the Sun of righteousness has arisen upon them with healing in His wings. One sad feature in our work is the recruiting of natives for employment on boats where they contract consumption and so swell the list of deaths considerably. Over 100 men were recruited here during the past year. Another serious evil arises in connection with the recruiting of young men.

Through their being absent for a considerable time from their tribes they lose to a great extent their rights and the old men become the possessors of a plurality of wives and do not hesitate to lend their superfluous spouses to unprincipled men of various nationalities for a small compensation. Such dealings are not only detrimental to the women, but has [sic] a demoralizing effect, on all, to the lowest degree."3

The other report, by Police Commissioner William Parry-Okeden, suggested a solution:

I think that beche-de-mer and turtle fishing, if worked under proper supervision for the benefit of the aborigines, would prove a most suitable outlet for their labour, possessing as it does such relation to their native occupation of hunting as to be congenial to their nature and habits, and harmonising perfectly with the idiosyncrasies of the coast black, and if successfully carried on it would turn out to be of valuable financial assistance in carrying out any scheme for the general amelioration of the blacks. ${ }^{24}$

Hey wrote in the same year:

22 Archibald Meston, 'Report on the Aboriginals of Queensland', QVP, vol. 2, 1896, pp. 723-40.

23 Hey, 1 July 1897, Report to the Colonial Secretary on the State and Progress of the Mapoon Mission Station, Mf 186, AlATSIS.

24 Parry-Okeden, op. cit. 
the work on the boats is detrimental to the health of the natives, which need not necessarily be so if worked under proper supervision, possessing as it does such relation to their native occupation of fishing as to be congenial to their habits and harmonizing with the idiosyncrasies of the blacks on the coast ... If at least part of the wages of these young able-bodied men would be paid into the Government Savings Bank and used for the benefit of their old parents young brothers and sisters, or for the general amelioration of the blacks the recruiting of natives would be somewhat justified. ${ }^{23}$

Again, it is likely that Hey's report (sent in July 1897) was written after ParryOkeden's (published in 1897). Hey's accounts make no acknowledgement of the authors to whom he owed his interpretation of events. Perhaps he may be excused for borrowing phrases from speakers of English more competent than himself. But though it was positioned as the record of an eyewitness, much of Hey's substantive knowledge can be traced to the official visitors to the mission. Thus, in order to give an estimate of the earnings from lugger work before a royal commission, Hey cited, in turn, Chief Protector Roth:

Once a boat returned with ten boys. Dr. Roth was at Mapoon at the time, and I requested him to go to the beach and see what the boys had brought with them. After doing so he said that all they brought back would be dear at $£ 1$, and they should have had $£ 5$ each. ${ }^{26}$

From this particular observation, made in 1900, Hey generalised in 1908 that 'only about one-fifth of their wages reach the station'. This suggests that he had not gathered any further information on the subject during these eight years.

These excerpts illustrate the circulation of knowledge on which a discourse of Aboriginal administration was founded. These sources consciously acted as eyewitness, primary sources, and appeared to validate each other, despite the fact that the knowledge was recycled.

\section{Lugger work: 'the chief trouble'}

The 'chief trouble' (Meston's phrase) was seen to rest in traditional gender relations. In these accounts, the polygynous social system stands as a facilitator of prostitution. The 'selling' of women formed a single explanatory complex with the polygamous marriage system, since a man who had more than one wife, therefore had 'superfluous spouses'. Like all Christian missionaries, Hey waged a battle against polygamy, which he referred to as 'evil' and 'the work of the devil'.

In this struggle, the missionaries had the support of the government. When John Douglas referred to 'illicit intercourse with native women' (as he frequently

25 Hey, 1 July 1897, Report to the Colonial Secretary on the State and Progress of the Mapoon Mission Station, Mf 186, AIATSIS.

26 Hey evidence in 'Report of the Royal Commission Appointed to Enquire into the Working of the Pearl-shell and Bêche-de-Mer Industries'. (Chairman J. Mackay), QVP, vol. 3, 1908; p. 218. 
did $)^{27}$ it is unlikely that the government resident, as the representative of British law on Thursday Island, was referring to native law. Most accounts suggest that such relations were sanctioned by local native communities and not considered illicit. Indeed, it was the way in which these communities were seen to encourage, even solicit, such relations that was abhorrent to white observers. ${ }^{28}$

According to Hey, the contact with luggers was poisoning the minds of Aboriginal women to the extent of introducing infanticide. ${ }^{29}$ To explore the structural logic of Hey's opposition to the lugger industry we must examine his role at Mapoon. Hey once described himself as a Moses leading the tribe of Israel, appropriately enough drawing a likeness between himself and the patriarch. ${ }^{30}$ What were his precise objections to the cross-racial contact?

The men in charge of boats remained there for some days, sometimes for some weeks, and lived among the natives, and by bribery induced them to go away with them in the boats ... The bribes were given to the more influential members of the tribe, so that the relatives left behind were the persons who were benefited."31

Bribery was given as the major objection to these transactions. It refers to the giving of flour and other trade goods to elders to obtain consent to recruit. Of course Hey knew how important such a material exchange was. In order to recruit children into the dormitory, he gave gifts of flour to the parents. By substituting one term for another, a different history emerges.

We must assume that the objection was not to the giving of flour. The elder males were seen to receive trade goods in return for hiring out young men and women to the recruiters. Perhaps the bribery rested in this selling of women and men. But Hey cannot have objected to the commodification of labour, nor to the fact that wages were paid in kind rather than cash, because he himself employed. labour on this basis.

Perhaps the objection was that the benefit accrued to the families of those engaged, rather than to the recruits themselves. Yet, in 1899, when he became inspector of those recruited for the fishery, Hey reported with satisfaction that

27 'Life on board one of these boats, or at the stations on the islands which are resorted to, is unspeakably squalid and dirty. For some men, however, it has an attraction, and there is often associated with it a good deal of illicit intercourse with native women. It is altogether a nasty stinking business, and at the present time it yields very small profits to anyone connected with it.' Douglas to Colonial Secretary, 16 February 1893, printed as appendix B in 'Report of the Government Resident at Thursday Island for 1892-3', QVP, vol. 2, 1894, pp. 14-15.

28 Indigenous laws and customs were often transgressed in these interactions, resulting in reprisals. It makes little sense to say that indigenous communities across the board either encouraged or discouraged women's interactions with colonisers. Indigenous communities did, however, draw the boundaries of appropriate conduct differently from the colonisers.

29 'Yet a still worse case came under my notice. Three young native women, who were with their husbands engaged on one of these boats, killed their infants who were born to them. Such unnatural cruelty has never occurred here and I can not believe that even the thought of such a thing originated in the minds of the cruel mothers. I can well understand that babies are not wanted on boats.' Hey, I July 1897, Report to the Colonial Secretary on the State and Progress of the Mapoon Mission Station, Mf 186, ALATSIS.

${ }^{30}$ Hey, Annual Report for Mapoon, 1907, Mf 186, AlATSIS.

3 Hey evidence in 'Report of the Royal Commission', p. 217. 
he was now holding back 'a part of their wages for days of illness'. ${ }^{32}$

Having put his wages into the common fund, each boy, as a matter of right, can also draw from the store anything he wants in reason-e.g. fishhooks, lines, turtle-rope, knives, tools, nails, buckets, further supply of clothing and tobacco, and, when he marries, the galvanized iron to roof his house. At Christmas time the store supplies every visitor (including, of course, those from Albatross Bay), with a suit of clothes. Each boy thus learns that he is labouring not only for himself, but for the common good.33

Labouring for the common good could hardly be a new lesson for people who sold themselves for the benefit of those who stayed behind. But now, equipped with new powers conferred by the Queensland government Hey, rather than the elder males, was at the helm of the distribution of benefits from outside earnings and access to such earnings was reserved for men. In the following year, Chief Protector of Aborigines Walter Roth was able to report that:

In a letter received from Rev. Mr. Hey, he tells me that, notwithstanding the shipping of 104 young men from Mapoon during the past twelve months he has now no complaints to make, that the spending by him, for the benefit of the boys, of a portion of their wages earned on the boats, promises to become a great factor in their civilization. ${ }^{34}$

The signing up of 104 men at Mapoon occurred against the backdrop of a steady population of about 100 at the mission. Given a choice between staying at the mission and signing up with the luggers, the men obviously saw the luggers as the more alluring prospect. Soon afterwards, Hey started the mission's own pearlshelling enterprise and, by 1906, the mission ran four boats, which became its main source of income. Hey, in charge of hiring and firing and bookkeeping, made no further reference to the ill health caused by working the boats. An activity that traditionally involved women had been transformed into a male industry.

Hey's objections to recruiting were couched in terms of health and morality. But they were not directed against men's participation in a dangerous industry. The waning of his objections suggests that issues of control and power were inseparable from the ethical and moral concerns raised by Hey.

Reading accounts of Aboriginal contact with the pearl-shell industry, one might almost forget that most of the men who came ashore at Mapoon were Asian. But it was the fear of miscegenation that united the church and the state over Aboriginal management. Hey's accounts suggest that traditional society provided no barrier to miscegenation and that it was for the protection of women that the peari-shellers needed to be controlled. He was given government authority in order to do so, and to manage and contain mixed-descent children. It is not entirely surprising that both missionary and official sources abound with anecdotes

\footnotetext{
32 Hey to La Trobe, Annual Report for Mapoon, 1899, Mf 186, AIATSIS.

${ }_{33}$ Walter Roth, 'Annual Report of the Northern Protector of Aborigines', QVP, vol. 2, 1902, p. 555.

${ }^{34}$ Walter Roth, 'Annual Report of the Northern Protector of Aborigines for 1899', QVP, vol. 5, 1900, p. 589.
} 
of outrages-the discourse of Aboriginal protection was founded on the abuse of Aboriginal women.

Hey's objection to the recruiters fundamentally concerned the receipt of discretionary income by women. The missionaries strongly objected to the way women participated in forging new and lasting exchange relationships, because a whole gendered moral universe was offended by such an arrangement. ${ }^{35}$ Noel Loos has observed with reference to the North Queensland missions that there was 'very little in Aboriginal life that did not offend the missionaries', but most of all they objected to the role of women. ${ }^{36}$

\section{A new order: Christian families}

Aiming to form Christian families, the missionary struggled to secure the power to sanction sexual partnerships. He used his control of desirable resources to do this. To monogamous couples he allocated a tin roof and a small farming allotment at an outstation. Visitors to the mission were impressed by Hey's patriarchal grip on the community. The police commissioner observed in 1897:

Mr. Hay [sic] speaks the Mapoon dialect, and settles all disputes by appealing to their sense of right. He also arranges marriages. No young man can get a wife till he has, by his behaviour, proved to Mr. Hay he is deserving. ${ }^{37}$

In 1906 Hey received unexpected government assistance in his effort to implement monogamy at Mapoon:

The problem of what shall become of our grown-up half-caste girls is solved inasfar as the government has burdened me with the job of finding young men outside the station, a peculiar role. In the Torres Strait Islands where the London Missionary Society works there is a shortage of women and I have already had several requests from there. Even requests from Europeans are occasionally received. By this means we expect to lose three of our best baptized girls this year. ${ }^{38}$

Hey did not state how he responded to the European requests. He had now successfully appropriated the role of the male elders in allocating material resources

3s James Ward who worked beside Hey at Mapoon for the first few years, wrote, 'If all these men were Christians, one might be quite content to let the blacks go with them; but too many of them are utterly irreligious, and I do not know one who ever spoke to the aborigines of Jesus Christ. Let me take these very men as examples, and you will see what manner of men we have to deal with. One has a wife in Thursday Island and a black concubine on another island. The others live openly in concubinage with blacks from neighbouring islands'. Arthur Ward, The Miracle of Mapoon, or, From Native Camp to Christian Village, Partridge, London, 1908, p. 132. The new order relegated sexuality, and women, to the private sphere. When submission is the only appropriate expression of female sexuality, right of access is fixed by public consensus; in these circumstances, sexuality cannot be a source of strength or a bargaining point beyond the acquisition of a first husband.

36 Loos, op. cit., p. 109.

37 Parry-Okeden, op. cit.

${ }^{38}$ Hey, Annual Report for Mapoon, 1906, Mf 186, AIATSIS. 
and regulating sexual relations: he had restructured social relations from polygamous gerontocracy to monogamous patriarchy. Having condemned the elder males for having an interest in the liaisons of the young women, Hey now took it upon himself to order young women into monogamous marriage. On hearing this news, the Aurukun girls dug a hole under the wall of the dormitory and fled the mission. ${ }^{39}$

Hey waged a full-scale battle against tradition. He argued that: "The cultural elevation of our people is inevitably necessary, mainly because the living conditions of the aborigines would render a Christian life impossible'.40 This cultural reorganisation required the moral condemnation of the social order that preceded it:

A very unfavourable characteristic of our people is their untruthfulness. 'What is truth?' is their implicit motto and their immorality is the downfall of the people. Venereal diseases especially syphilis cause great damage among the aborigines. That idleness and sloth, which, according to the old adage, is the root of all evil, is properly confirmed in this poor people.41

The condemnation of the old order was not an innocuous superimposition of cultural assumptions but part of an active agenda of reordering social relations and, in the process, colonising gender. Hey was appropriating the power of the elders and this struggle informed the logic of his evidence, given for two parliamentary reports and a 1908 royal commission. ${ }^{42}$

\section{A lineage of knowledge}

No anthropological training was available for the missionaries who went into the field and Hey's correspondence from Mapoon reflects some serious misreadings of Aboriginal customs and cosmology, for example:

The whole nation knows very little of tradition. Only a few superstitious ideas are among them. With great effort I was able to find out this much, that some of them still have a faint idea that the good ones go to a good place whereas the bad ones go to a bad one. What they mean by good and bad is difficult to say ... For the female sex they think there is no eternity because for them the women are only instruments which after they become useless have no further value. ${ }^{43}$

\footnotetext{
39 After they had been told that they could accompany the missionaries to Mapoon for the church opening, all the girls fled from the Aurukun dormitory. They had heard that the protector of Aborigines wanted to marry the girls off to Islanders, and believed that this was why they would be taken to Mapoon. 'For several months all children, boys and girls, avoided us ... We still have no girls and will build a more secure girls' house like the older stations', Arthur Richter reported. A. Richter, Annual Report for Aurukun, 1907, Mf 17I, AlATSIS.

40 Hey, Annual Report for Mapoon, 1902, Mf 186, AIATSIS.

41 Ibid.

42 Mackay, op. cit., pp. 1-284. The two reports are by Meston (1896) and Parry-Okeden (1897).

43 Hey to [O']Connor, 11 May 1893, Mf 168, AlATSIS.
} 
Australian ethnography was only just emerging at the turn of the century and it developed in close association with the missionaries and settlers, who could give first-hand observations in response to circulated questionnaires or visits from ethnographers. Hey, too, was consulted by at least two ethnographers, although he expressed reluctance about immersing himself in the culture of 'his people'.44 He replied to R.H. Mathews:

in order to become well acquainted with the old customs of the blacks it is essential to enter into all their little doings and know their traditions and there is always a great deal of filth and other obscene ideas connected with them, and it is not in our interest to show any great desire to enter into, but rather to abhor these things. ${ }^{45}$

Hey cannot be singled out as a particularly moralising or ill-informed observer. As a missionary, he saw it as his business to moralise-to condemn and criticise un-Christian practices, to abhor rather than enter into them. In the same way, Christopher Anderson has observed with reference to the Bloomfield River missionaries, that they rarely recorded personal names and 'no real awareness is demonstrated of the reality or specifics of an Aboriginal way of life'. ${ }^{46} \mathrm{Hey}^{\prime} \mathrm{s}$ commentaries did not constitute, and were not intended as, bland description but served to justify the raison d'ettre of his mission and defend his actions: in his correspondence, the description supplied was only sufficient to illustrate his conclusions. Whatever we may think of the missionary enterprise itself, Hey was regarded as 'one of the great modern missionaries'. ${ }^{47}$ He worked hard and argued fervently for what he felt was best for 'his people'. Many of the older people at Mapoon remember him fondly.

But it is troubling that ethnographers sought and accepted advice from Hey, who was so slow to demonstrate an understanding of the traditions around Mapoon. One of our most useful written sources on contact relations at Cape York is based on this kind of evidence. The series of ethnographic bulletins by the noted Dr Walter Roth, the first chief protector of Aborigines in Queensland, frequently refer to statements made by local observers, including Hey:

44 Hey replied five times to Mathews, who was sending out questionnaires to people in the field. His first response, given above, in August 1899 expressed his reluctance to gather the data required. Still, he briefly described the geographical boundaries of the three Mapoon tribes. His second letter in October 1899 pointed out that Roth was already conducting a comparative study so that there was no need to go into further particulars: 'I may also state that I am not very fond of this particular work because I get too much of it and I have so many things to attend to that I can not afford time to have a particular "hobby". He provided a map which showed the two groups and four sections of the Jingunjie (Batavia River tribe). 'Owing to the advancement of civilization it is not possible to give a true separate list of "totems" belonging to the various sections of the Mapoon tribe.' His fourth letter, in August 1900, finally gives all the section names. His fifth and last letter, in October 1901, simply states that he cannot comply with Mathews' request. R. H. Mathews collection. MS 8006, series 2, Correspondence, National Library of Australia.

4 N. Hey to R. Mathews, 4 August 1899, ibid.

to Christopher Anderson, 'A Case Study in Failure: Kuku-Yalanji and the Lutherans at Bloomfield River, 1887-1902', in Swain and Rose (eds). op. cit., p. 333.

47 J.E. Hutton, Extracts from History of Moravian Missions, Moravian Publicity Office, n.p., n.d., cited in Loos, op. cit., p. 108. 
An old woman, as a rule, receives but scant consideration, though she may be looked after by her sons when neglected by her husband ... When, however, unable to provide for herself, or too infirm to accompany her younger relatives and dependants on their journey, she may either be left behind to starve, or perhaps even put to death. Rev. Hey, on the Batavia River, mentions two cases of old women whom the blacks proposed burying alive: they were 'no more good'. ${ }^{48}$

In this passage, Hey's evidence substantiates the generalised pronouncement about women's role. Roth's view of gender relations in Aboriginal society (recorded in his ethnographic bulletin on Aboriginal sexuality) was substantially constructed from such sources. This essay has cast some serious doubt on the reliability of Hey's evidence on questions of gender and Aboriginal womanhood. Is it reasonable to assume that other local informants were similarly swayed by their own moral agenda? Or, to rephrase the question, is it reasonable to assume that they were not? ${ }^{49}$

Roth himself was an acute observer of indigenous customs from basketmaking to body decoration and canoe construction. When it comes to women's position, however, we see his account burdened with interpretation:

Amongst the Bloomfield River natives .... divorce is allowed to either party, although the weaker vessel does not usually resort to such a measure unless well backed by powerful relatives. If the husband wishes to free himself, he generally arranges the miatter quietly with one of his group-or blood-brothers, gets him to take her, and holding her by the wrist, hands her over. 30

The assumptions built into this passage are that woman is the weaker vessel, man wishes to free himself of her whereas woman has to 'resort' to such a measure. When stripped of these unsubstantiated presumptions, we learn in this passage that the symbolic expression of a marriage was the man taking the woman by the wrist but that both parties could initiate divorce and both required family backing to withdraw from a marriage. A neutral reading puts a quite different gloss on the procedure.

4s Walter Roth, 'North Queensland Ethnography, Bulletin No. 8, Notes on Government, Morals and Crime', Government Printer, Brisbane, 1906, p. 8.

49 Another of Roth's informants wrote the following account: 'On the Tully River ... nothing is thought of elder men, provided they belong to the suitable marriageable group, tampering with any young girls, quite young children being actually handed over to the old men with a view to their being "broken in" (E. Brooke)'. Roth, op. cit., pp. 6-8. We are left to speculate on how Brooke at the Tully River ascertained the intention of the observed ritual. A different passage suggests strongly that the young girls were not handed over with a carte blanche for sexual intercourse. A man had to be already married to be entrusted with a young girl. Walter Roth, 'North Queensland Ethnography, Bulletin No. 10', Government Printer, Brisbane, 1908, p. 15. Some female authors have suggested that the rights vested in such a husband did not include sexual intercourse with a pre-mature girl. See Ruby Rohrlich-Leavitt, Barbara Sykes and Elizabeth Weatherford, 'Aboriginal Woman: Male and Female Anthropological Perspectives', in Rayna Reiter (ed.), Toward an Arthropology of Women, Monthly Review Press, New York, 1975, p. 117; Phyllis M. Kaberry, Aboriginal Women: Sacred and Profane, George Routledge, London, 1939. passim:

so Roth, 1908, op. cit., p. 11-12. My emphases. 
It is as if the weakness and powerlessness of the women renders Aboriginal society familiar and decipherable. Against a backdrop of women's general powerlessness, Roth did acknowledge that the older women often had an important say in many matters and, occasionally, the younger females (e.g. on the Bloomfield) took part in the deliberations." ${ }^{31}$ He even observed the direct responsibility of women over certain areas of land, although the way he reported it downplays this source of power:

The only instance known to me of women holding what might almost be called real estate is on the Bloomfield, where the patches of zamia plants (edible) are apportioned amongst the females, each woman bequeathing her lot to her daughters or other female relatives. ${ }^{32}$

Noting the instrumental value of this plant is a semantic device that serves to explain, and devalue, a locus of women's power.

Roth was a distinguished ethnographer. His meticulous ethnographic notes were ground-breaking and he went on to receive many honours in ethnography. His texts have become a key source for subsequent anthropologies and histories, including my own account of the removal of the Wappaburra people from Keppel Island. ${ }^{33}$ An attempt to reconstruct traditional gender relations from such sources is, however, highly problematic. Writing in 1984 about Bloomfield River, anthropologist Chris Anderson made frequent reference to Roth to substantiate an interpretation of traditional gender relations. Implicitly referring to the above passage from Roth, which describes the marriage ceremony ('holding her by the wrist'), Anderson concluded that:

The betrothal or 'promise' system of marriage and the marriage ceremony itself aptly demonstrate the dominance of older males and give an indication of male/female relations in Kuku-Yalanji society ... The crucial and defining element of Kuku-Yalanji social relations of production was the domination of younger men and all women by older Kuku-Yalanji men. 54

The source of the power of elder men, according to Anderson, was the polygynous marriage, because it enabled a husband to command the labour of women and their relatives. This meant that women had an instrumental value as wives. Anderson argued convincingly that older males were more powerful than younger ones (who could not marry until initiated), but the subordinate position of women in polygynous marriage is presumed rather than demonstrated. He argued this point against the stated opinion of his informants and relied instead on the written testimony of whites:

s1 Roth, 1906, op. cit., p. 5.

32 Ibid., p. 9.

33 Regina Ganter, The History and Development of the Keppel Islands, BA Hons thesis, Griffith University, 1985.

54 My emphasis. The material expression of that dominance was that 'Food resources, often staples and highly desired items, were generally channelled in favour of males over females, and in favour of older males over all others'. Jon Christopher Anderson, The Political and Economic Basis of Kuku-Yalanji Social History, PhD thesis, University of Queensland, 1984, pp. 128, 326. 
The instrumental value of women is denied, although clearly recognised in practice by the attempts to gain and maintain control over the reproductive capacity of women. Nevertheless, Kuku-Yalanji women's status in the domestic arena was very much a subordinate one. There are numerous historical references to this in [South East Cape York Peninsula]. (Rowan 1912:115, 126, Hodgkinson 1886:9. $)^{55}$

When Anderson probed for problems that might obtain in this family structure, the women sought to demonstrate the sources of power they could tap in such marriages and 'stressed the advantages of the system for women in having others to share domestic labour and also in being able to join forces against the husband, if necessary". ${ }^{56}$

Anderson did argue (and this is the central thrust of his argument) that the contact period proffered new access to power for the most oppressed in Aboriginal society: young males and all women. ${ }^{57}$ He thus easily conceded that, during the process of social change induced by contact, women might have become agents rather than victims of change-but the old Kuku-Yalanji social system rested on the exploitation of all women and young men by those who had several wives.ss

The aim here is not to test whether traditional Aboriginal women might have been oppressed by their men. The question of the 'gender balance of power' in traditional Aboriginal society is a most divisive one in Australian anthropology. It erupted with new ferocity over the Hindmarsh Island affair and the question of 'secret women's business'. ${ }^{59}$ A now substantial body of women's anthropology $y^{60}$ has offered a critique of the masculinist tradition of ethnography, which arguably creates a male-centred view through its own dynamics (male fieldworkers, male informants), and a consensual view on traditional gender relations is unlikely to emerge. The argument here is, rather, that such oppression is inferred as a selfevident result of the polygynous system of marriage and its associated practices (promise system, marriage bar)-rather like the primary texts that saw the "chief

"3s My emphases. Ibid., p. 132.

36 lbid.

57 lbid., p. 321.

58 lbid., p. 324.

"Lyndall Ryan and Richard Nile (eds), Secret Women's Business: The Hindmarsh Island Affair, University of Queensland Press, Brisbane, 1996.

so Such questions are raised in a now substantial literature. See: Kaberry, op. cit.; Marie Reay, "The Social Position of Women', in Helen Sheils (ed.), Australian Aboriginal Studies: A Symposium of Papers Presented at the 1961 Research Conference, Oxford University Press for the Australian Institute of Aboriginal Studies, Melbourne, 1963, pp. 319-34; Isobel White, 'Aboriginal Women's Status: A Paradox Resolved', in Fay Gale (ed.), Woman's Role in Aboriginal Society. Australian Institute of Aboriginal Studies (ALAS), Canberra, 1970, pp. 39-49; Jane Goodale, Tiwi Wives: $A$ Study of the Women of Tiwi Island, North Australia, University of Washington Press, Seattle, 1971; Catherine Berndt, "Women and the "Secret Life"', in R.M. and C.H. Berndt (eds), Aboriginal Man in Australia, Angus 6 Robertson, Sydney, 1965, pp. 238-82; Catherine Berndt, Digging Sticks and Spears, or, the Two-sex Model', in Gale, op. cit., p. 39-48; Annette Hamilton, 'Dual Social Systems: Technology, Labour and Women's Secret Rites in the Eastem Western Desert of Australia', Oceania, vol. 51, no. 1. September 1980, pp. 4-19; Annette Hamilton, 'A Complex Strategical Situation: Gender and Power in Aboriginal Australia', in Norma Grieve and Patricia Grimshaw (eds). Australian Women: Feminist Perspectives, Oxford University Press, Melboume, 1981, pp. 69-85: Diane Bell, Daughters of the Dreaming. McPhee Gribble, Melboume, 1983. 
trouble' with having 'a plurality of wives'. Moreover, this conclusion is substantiated with reference to just such primary texts. Clearly the 'historical references' must be tempered by locating them in the contact period, which was characterised by rupture, violence and change. Using such texts as a window into traditional society is highly problematic.

The problem is clearly not Anderson's alone. Similar slippages may be found in the work of most historians and anthropologists when reference is made to the sexual/race relations in the pearl-shelling industry during that contact period. Accounts of this industry are commonly characterised by reference to 'prostitution' and 'bribery' based, either directly or indirectly, 'on the sources discussed above. Henry Reynolds cites Douglas to point to 'a good deal of illicit intercourse with native women' (cf. note 27). Gaynor Evans, whose portrayal of sexual/race relations in the marine industries is substantially based on accounts from Roth, Parry-Okeden, Douglas, Hey and Ward, is cited by Jeremy Beckett as arguing that Aboriginal women were habitually abducted by masters 'to serve the sexual needs of their foreign crew'. Her work is also cited in Ross Fitzgerald's History of Queensland to declare that 'fishing crews were rightly considered to be "the lowest of the low". Aboriginal women were usually prostituted, leaving a legacy of disease'. This evidently stems from Parry-Okeden's report (cf. note 1). ${ }^{\text {.1 }}$

Accounts from other missions, from Cooktown, as well as from pearling centres outside Queensland-also authored by missionaries and state officerscorroborate this portrayal. However, a close scrutiny of the conditions of production of such texts renders the project of corroboration suspect, something which has been noted by those who have engaged closely with these sources. Steve Mullins' history of the contact period in Torres Strait problematises the 'bad press' of the marine industries, arguing that a distinction must be drawn between what 'offended the moral sensibilities of missionaries' and what constituted an abuse of the rights and welfare of recruits. My own account of the pearl-shell industry in Torres Strait concluded that: "The surviving accounts of relationships between white or Japanese skippers and Aboriginal women are too much coloured by moral condemnation to render such interaction intelligible' ${ }^{62}$

\section{Conclusion}

The oppression of women through the system of polygynous marriage is neither questioned nor demonstrated in the lineage of texts leading to Anderson's

6t Gaynor Evans, Thursday Island, 1878-1911: A Plural Society, BA Hons thesis, University of Queensland, 1972, pp. 11, 116, 121, 123; Jeremy Beckett, Torres Strait Islanders: Custom and Colonialism, Cambridge University Press, Cambridge, 1987, p. 33; Ross Fitzgerald, A History of Queensland, vol. I, University of Queensland Press, Brisbane, 1986, p. 208; Henry Reynolds, With the White People, Penguin, Melbourne, 1990, p. 223.

62 Steve Mullins, Torres Strait: A History of Colonial Occupation and Culture Contact, 1864-1897, Central Queensland University Press, Rockhampton, 1995, p. 62; Regina Ganter, The Pearl-Shellers of Torres Strait, Melboume University Press, Melbourne, 1994, p. 4. 
portrayal and the historical references to sexual/race relations in the pearl-shell industry leave no room to question the validity of labels such as 'prostitution' or 'bribery'. The very lexicon is a prism of moral inflections carried over covertly from text to text.

Such slippage impedes the project of decolonisation. Officers of the church and the state had some real basis for opposing polygamy and for condemning practices of a traditional society they sought to topple--but the anthropologists and historians who absorb such judgements do not. There is no need to continue to invest into a colonising discourse on Aboriginal womanhood.

Instead of sketching a genealogy of knowledge of traditional societies on Cape York, this article has traced a particular lineage through a much larger tree of textual references. This is not to single out particular authors for criticism so much as to remind us how burdened our sources are. The Marpuna Aboriginal Corporation has been seeking to assemble documented references to the languages, customs and traditions of the Wik Munkan people, such as might be contained in the observations and accounts left by missionaries, protectors, settlers and early ethnographers. Pondering the dearth of comments useful to their endeavour to be gleaned from Hey's correspondence, it seems that they are ill served not so much by any particular author but by the whole enterprise of Western knowledge production. 